\title{
Peningkatan Hasil Belajar PKn Melalui Metode Numbered Head Together Berbantuan Multimedia di SD Negeri 050748 Pangkalan Berandan Tahun Pelajaran 2016-2017
}

\author{
Masniah \\ SD Negeri 050748 Pangkalan Berandan, Langkat, Sumatera Utara \\ E-mail: masniah@gmail.com
}

\begin{abstract}
Abstrak
Tujuan dalam penelitian ini adalah untuk meningkatkan hasil belajar PKn melalui metode Numbered Heads Together berbantuan multimedia pada siswa di SD Negeri 050748 Pangkalan Berandan Tahun ajaran 2016-2017. Penelitian ini merupakan penelitian tindakan kelas yang terdiri dari 2 siklus. Dari hasil penelitian dapat diketahui hasil belajar siswa mengalami peningkatan disetiap siklusnya. Hal itu dapat dilihat dari perolehan data pada siklus I yang nilai rata-ratanya mencapai 71,11 dengan persentase ketuntasan mencapai 66,66\%. Dan pada siklus II nilai rata-rata mencapai 80 dengan persentase ketuntasan mencapai 83,33\%. Penelitian ini menyimpulkan bahwa dengan menggunakan metode Numbered Heads Together berbantuan multimedia dapat meningkatkan kualitas pembelajaran PKn pada siswa kelas V SD Negeri 050748 Pangkalan Berandan Tahun Pelajarn 2016-2017. Dari hasil yang diproleh, Metode Numbered Heads Together berbantuan multimedia bisa menjadi alternatif metode meningkatkan hasil belajar sisiwa
\end{abstract}

Kata Kunci: Hasil Belajar, Metode Numbered Heads Together, multimedia.

\section{Abstract}

The purpose of this research is to improve the learning outcomes of PKn course through the Numbered Heads Together method with assisted multimedia on the students in SD Negeri 050748 Pangkalan Berandan year 2016-2017. This study is a classroom action research consisting of 2 cycles. From the results, the learning outcomes can be have increased in each cycle. It can be seen from the data acquisition in the first cycle that the average value reached 71.11 with the 
percentage of completeness reached $66.66 \%$. And in second cycle, the average value reached 80 with the percentage of completeness reached $83.33 \%$. This study concluded that by using the Numbered Heads Together method with multimedia aids can improve learning outcoems of student in SD Negeri 050748 Pangkalan Brandan year 2016-2017. Therefore, Numbered Heads Together Method with assisted multimedia can be an alternative method of improving learning outcomes of student.

Keywords: Learning Outcomes, Numbered Heads Together Method, multimedia.

\section{A. PENDAHULUAN}

Pendidikan nasional merupakan sebuah sistem yang dalam penerapannya menuju tercapainya tujuan pendidikan nasional. (Sisdiknas, 2005:6). Di Indonesia pelaksanaan pendidikan nasional bertitik tolak pada standar nasional pendidikan. Standar nasional pendidikan digunakan sebagai acuan pengembangan kurikulum yang diterapkan pada tiap jenjang pendidikan. Salah satu kurikulum yang digunakan adalah kurikulum tingkat satuan pendidikan (KTSP).

Berdasarkan Peraturan Pemerintah No. 22 Tahun 2006 menyebutkan kurikulum SD/MI memuat delapan mata pelajaran salah satunya yaitu Pendidikan Kewarganegaraan. Tujuan dari mata pelajaran Pendidikan Kewarganegaraan agar peserta didik memiliki kemampuan sebagai berikut: (a) berpikir secara kritis, rasional, dan kreatif dalam menanggapi persoalan hidup maupun isu kewarganegaraan; (b) berpartisipasi dalam segala bidang kegiatan, secara aktif dan bertanggung jawab, sehingga bisa bertindak secara cerdas dalam semua kegiatan dan; (c) berkembang secara positif dan demokratis sehingga mampu hidup bersama dengan bangsa lain di dunia dan mampu berinteraksi, serta mampu memanfaatkan teknologi informasi dan komunikasi dengan baik. Hal ini mudah tercapai jika pendidikan nilai moral dan norma tetap ditanamkan pada siswa sejak usia dini, karena jika siswa sudah memiliki nilai moral yang baik, maka tujuan untuk membentuk warga negara yang baik mudah diwujudkan.

Depdiknas (2007:25) menemukan permasalahan pada pelaksanaan pembelajaran PKn di SD kelas V lebih pada kurang 
kreativitas dan inovasi dalam pembelajaran, guru kurang maksimal dalam melaksanakan pembelajaran yang partisipatif dan dalam penggunaan media pembelajaran. Selain itu metode pembelajaran dalam Proses Belajar Mengajar (PBM) terkesan sangat kaku, kurang fleksibel, kurang demokratis, dan guru cenderung lebih dominan (one way method). Jika hal demikian tidak diatasi lama kelamaan proses kebosanan dan kejenuhan siswa dapat memuncak berakibat pada menurunnya hasil belajar siswa.

Permasalahan pembelajaran PKn adalah hampir serupa dengan permasalahan yang terjadi di SD Negeri 050748 Pangkalan Berandan Tahun Pelajaran 2016-2017. Berdasarkan obeservasi hal itu terjadi dikarenakan keterampilan mengajar guru yang masih rendah. Keterampilan guru mengelola kelas kurang berjalan dengan baik sehingga menyebabkan kondisi kelas kurang kondusif. Keterampilan menjelaskan yang kurang maksimal, guru hanya menjelaskan materi dan siswa mendengarkan penjelasan guru. Keterampilan guru mengadakan variasi dalam penggunaan alat bantu pengajaran berupa media pembelajaran belum efektif digunakan dalam pembelajaran PKn karena kurang sesuai dengan materi pelajaran.

Keterampilan mengajar guru yang masih rendah berdampak pada hasil belajar siswa menjadi rendah dan mendapat nilai dibawah KKM yang ditentukan. Untuk memecahkan masalah pembelajaran tersebut ditetapkan alternatif tindakan untuk meningkatkan hasil belajar pembelajaran PKn dengan pemilihan model pembelajaran. Peneliti menggunakan salah satu model pembelajaran yang sesuai dengan materi PKn yaitu menggunakan model Numbered Head Together (NHT) berbantu multimedia.

Numbered Head Together (NHT) merupakan suatu model pembelajaran berkelompok yang setiap anggota kelompoknya bertanggung jawab atas tugas kelompoknya, sehingga tidak ada pemisahan antara siswa yang satu dan siswa yang lain dalam satu kelompok untuk saling memberikan dan menerima antara satu dengan yang lainnya Kelebihan model antara lain : (a) setiap murid menjadi siap; (b) dapat melakukan diskusi dengan sungguhsungguh; (c) murid yang pandai dapat mengajari murid yang kurang pandai; (d) terjadi interkasi secara intens antarsiswa dalam menjawab soal; (e) tidak ada murid yang mendominasi dalam kelompok karena nomor yang membatasi. Agar model pembelajaran NHT dapat berjalan secara 
maksimal diperlukan media pembelajaran yang mendukung. Media pembelajaran yang mendukung model Numbered Head Together (NHT) adalah multimedia. Multimedia secara sederhana diartikan sebagai lebih dari satu media. Media tersebut berupa kombinasi antara teks, grafik, animasi, suara dan video. Multimedia secara umum dapat diartikan berbagai macam kombinasi grafik, teks, suara, video dan animasi. Penggabungan ini merupakan suatu kesatuan yang secara bersama-sama menampilkan informasi, pesan atau isi pelajaran. Pada penelitian ini, bagaimana cara meningkatkan hasil belajar Pkn melalui metode Numbered Head Together berbantuan multimedia pada siswa kelas V SD Negeri 050748 Pangkalan Berandan Tahun Pelajaran 2016-2017?

\section{B. TINJAUAN PUSTAKA}

\section{Hakikat Pendidikan Kewarganegaraan di SD}

Pendidikan Kewarganegaraan adalah upaya untuk membekali peserta didik dengan pengetahuan dan kemampuan dasar berkenaan dengan hubungan antara warga negara dengan negara agar menjadi warga negara yang dapat diandalkan oleh Bangsa dan negara kesatuan Republik Indonesia. Pendidikan Kewarganegaraan memiliki ciri-ciri sebagai berikut:

a. Materinya berupa pengetahuan dan kemampuan dasar berkenaan dengan hubungan antara warga negara dengan Negara

b. Bersifat interdisipliner;

c. Bertujuan membentuk warga negara yang dapat diandalkan oleh bangsa dan negara.

Berdasarkan ciri-ciri PKn dianalisis maka dapat disimpulkan bahwa Pendidikan Kewarganegaraan di Indonesia merupakan matapelajaran yang mengembangkan nilai kehidupan sebagai warga negara yang bertolak pada bidang studi yang serumpun. Pendidikan Kewarganegaraan (PKn) diartikan sebagai mata pelajaran yang memfokuskan pada pembentukan warga negara yang memahami dan mampu melaksanakan hak-hak dan kewajibannya untuk menjadi warga negara Indonesia yang cerdas, terampil dan berkarakter yang diamanatkan oleh Pancasila dan UUD 1945. Pendidikan Kewarganegaraan memiliki misi sebagai pendidikan kebangsaan Indonesia, pendidikan politik demokrasi di Indonesia dan pendidikan bela negara, pendidikan HAM, pendidikan multikultural, pendidikan 
lingkungan hidup, pendidikan hukum dan pendidikan anti korupsi. Sebagai sebuah mata pelajaran, pembelajaran PKn merupakan proses pendidikan secara utuh dan menyeluruh terhadap pembentukan karakter individu sebagai warga negara yang cerdas dan baik. PKn adalah program pendidikan yang secara programik prosedural berupaya memanusiakan (humanizing) dan membudayakan (culturing) serta memberdayakan (empowering) manusia/anak didik (diri dan lingkungannya) menjadi warga negara yang baik dalam Negara Kesatuan Republik Indonesia (NKRI).

Berdasarkan uraian yang telah dikemukakan dan dianalisis, dapat disimpulkan bahwa tujuan PKn di SD adalah menjadikan warga negara yang taat pada pancasila dan Undang-Undang 1945, dalam pengembanganya tujuan $\mathrm{PKn}$ ingin menciptakan individu yang mengembangkan nilai luhur bangsa bermoral baik dan kreatif.

\section{Model Numbered Head Together}

Numbered Head Together (NHT) merupakan varian dari diskusi kelompok. Tujuan dari NHT adalah memberikan kesempatan kepada siswa untuk saling berbagi gagasan dan mempertimbangkan jawaban yang paling tepat. Selain untuk meningkatkan kerja sama siswa, NHT juga bisa diterapkan untuk semua mata pelajaran dan tingkatan kelas. Numbered Head Together (NHT) merupakan salah satu dari strategi pembelajaran kooperatif. Model NHT mengacu pada belajar kelompok siswa, masing-masing anggota memiliki bagian tugas (pertanyaan) dengan nomor yang berbeda-beda (Shoimin, 2014:107). Sukidin dan Surano (dalam Shoimin, 2014:108) menyebutkan setiap siswa mendapatkan kesempatan sama untuk menunjang timnya guna memperoleh nilai yang maksimal sehingga termotovasi untuk belajar. Dengan demikian setiap individu merasa mendapat tugas dan tanggung jawab sehingga tujuan pembelajaran dapat tercapai. Numbered Head Together (NHT) merupakan suatu model pembelajaran berkelompok yang setiap anggota kelompoknya bertanggung jawab atas tugas kelompoknya, sehingga tidak ada pemisahkan antara siswa yang satu dengan siswa yang lainnya dalam satu kelompok untuk slaing memberi dan menerima antara satu dengan yang lain. Numbered Head Together (NHT) atau penomoran berpikir bersama adalah jenis pembelajaran kooperatif yang dirancang untuk mempengaruhi pola interaksi siswa dan sebagai alternative 
terhadap struktur kelas tradisional. Numbered Head Together (NHT) pertama kali dikembangkan oleh Spenser Kagen untuk melibatkan lebih banyak siswa dalam menelaah materi yang tercakup dalam suatu pelajaran dan mengecek pemahaman mereka terhadap isi pelajaran tersebut. Peranan metode Numbered Heads Together dalam proses pembelajaran adalah sebagai berikut:

1. menyampaikan tujuan pembelajaran dengan jelas;

2. menempatkan siswa secara heterogen dalam kelompok-kelompok kecil;

3. menyampaikan tugas-tugas yang harus dikerjakan siswa, baik tugas individu maupun kelompok;

4. memantau kerja kelompok;

5. mengevaluasi hasil belajar.

\section{Unsur-unsur Model Numbered Head Together}

a. Sintakmatik

Menurut Trianto (2011:63) dalam mengajukan pertanyaan kepada seluruh kelas, guru menggunakan struktur empat fase sintak NHT yang terdiri:

Fase 1: Penomoran

Dalam fase ini, guru membagi siswa ke dalam kelompok 3-5 orang dan kepada setiap anggota kelompok diberi nomor antara 1 sampai 5.

Fase 2: Mengajukan Pertanyaan

Guru mengajukan sebuah pertanyaan kepada siswa, pertanyaan dapat bervariasi. Pertanyaan spesifik dalam bentuk kalimat tanya.

Fase 3: Berpikir Bersama

Siswa menyatukan pendapat terhadap jawaban pertanyaan itu dan meyakinkan tiap anggota mengetahui jawaban tim.

Fase 4: Menjawab

Guru memanggil suatu nomor tertentu, kemudian siswa yang nomor sesuai mengacungkan tangan dan mencoba untuk menjawab pertanyaan untuk seluruh kelas.

Langkah-langkah model Numbered Head Together (NHT) adalah sebagai berikut:

1. Siswa dibagi dalam kelompok. Setiap siswa dalam setiap kelompok mendapat nomor;

2. Guru memberikan tugas dan masing-masing kelompok mengerjakannya; 
3. Kelompok mendiskusikan jaawaban yang benar dan memastikan tiap anggota kelompok dapat mengerjakannya/mengetahui jawabannya dengan baik;

4. Guru memanggil salah satu nomor siswa dan nomor yang dipanggil keluar dari kelompoknya melaporkan atau menjelaskan hasil kerja sama mereka;

5. Tanggapan dengan teman yang lain, kemudian guru menunjuk $n$

6. Nomor yang lain;

Fase 5. Kesimpulan.

\section{b. Sistem Sosial}

Sistem sosial adalah situasi atau suasana dan norma yang berlaku dalam model tersebut. Suatu tata aturan yang dirancang dan disepakati untuk dijalankan dalam proses pembelajaran.

\section{c. Prinsip Reaksi}

Prinsip Reaksi adalah pola kegiatan yang menggambarkan bagaimana seharusnya guru melihat dan memperlakukan para pelajar termasuk bagaimana seharusnya pengajar memberikan respon terhadap mereka.

\section{Manfaat Model Numbered Head Together}

Ada beberapa manfaat pada model pembelajaran kooperatif tipe NHT terhadap siswa antara lain adalah: a) Rasa harga diri menjadi lebih tinggi; b) Memperbaiki kehadiran; c) Penerimaan terhadap individu menjadi lebih besar; d) Perilaku mengganggu menjadi lebih kecil; e) Konflik antara pribadi berkurang; f) Pemahaman yang lebih mendalam; g) Meningkatkan kebaikan budi, kepekaan dan toleransi; h) Hasil belajar lebih tinggi.

\section{Tujuan model Numbered Head Together}

Tiga tujuan yang hendak dicapai dalam pembelajaran kooperatif dengan tipe NHT yaitu: a) Hasil belajar akademik stuktural; b) Pengakuan adanya keragaman; dan c). Pengembangan keterampilan sosial

Dengan model NHT diharapkan dapat membangkitkan minat siswa dalam mengungkakan pendapat dalam bentuk rangkaian kata dan kalimat. Dengan demikian dapat disimpulkan bahwa peningkatan kemampuan merangkai kata secara runtut sangat diperlukan sekali 
guna membantu mengembangkan hasanah Bahasa Indonesia dalam kehidupan sehari-hari sebagai alat komunikasi atau meningkatkan rasa nasionalisme.

\section{Kelebihan dan Kekurangan Model Numbered Head Together}

Model Numbered Head Together (NHT) merupakan salah satu bentuk model kooperatif yang dapat diterapkan dalam pembelajaran yang ingin mengembangkan kerja sama dalam kelompok. Model NHT memiliki beberapa kelebihan dibandingkan dengan model pembelajaran yang lain. Kelebihan model Numbered Head Together (NHT) antara lain:

a. Setiap murid menjadi siap

b. Dapat melakukan diskusi dengan sungguh-sungguh

c. Murid yang pandai dapat mengajari murid yang kurang pandai

d. Terjadi interkasi secara intens antarsiswa dalam menjawab soal

e. Tidak ada murid yang mendominasi dalam kelompok karena nomor yang membatasi.

Sedangkan kekurangan dari model Numbered Head Together (NHT) antara lain:

a. Kemungkinan nomor yang dipanggil, akan dipanggil lagi oleh guru; b. Tidak semua anggota kelompok dipanggil oleh guru karena kemungkinan waktu yang terbatas.

Solusi untuk mengatasi kekurangan penerapan model Numbered Head Together (NHT) dalam pembelajaran berkaitan langsung dengan kemampuan guru dalam mengelola kelas. Guru dapat membuat daftar siswa yang akan maju sehingga kemungkinan nomor yang dipanggil, akan dipanggil lagi oleh guru. Selain itu untuk mengatasi ketidakmungkinan semua anggota kelompok dipanggil guru, guru dapat memanggil siswa yang memang dapat mewakili jawaban semua siswa di kelas. Maka dari itu guru harus mengenali karakteristik siswa yang berbeda didalam kelas sehingga dapat menjadi fasilitator yang menyebabkan proses pembelajaran berlangsung menyenangkan dan sesuai perencanaan.

\section{Pengertian Multimedia}

Multimedia berupa media yang melibatkan berbagai indera dalam sebuah proses pembelajaran. Termasuk dalam media ini adalah segala sesuatu yang memberikan pengalaman secara langsung bisa 
melalui komputer dan internet, bisa juga melalui pengalaman berbuat dan pengalaman terlibat. Multimedia berasal dari kata multi dan media. Multi berasal dari bahasa latin yaitu nouns yang berarti banyak atau bermacam-macam. Sedangkan kata media berasal dari bahasa latin medium yang berarti perantara atau sesuatu yang digunakan untuk menghantarkan, menyampaikan atau membawa sesuatu. Berdasarkan itu multimedia merupakan perpaduan antara berbagai media (format file) yang berupa teks, gambar (vector atau bitmap), grafik, sound, animasi, video, interaksi dan lain-lain yang telah dikemas menjadi file digital (komputerisasi), digunakan untuk menyampikan atau menghantarkan pesan kepada publik. Pengertian multimedia yang digunakan dalam penelitian ini adalah presentasi pembelajaran/instruksional yang mengkombinasikan tampilan teks, grafik dan audio serta dapat menyediakan interaktivitas.

\section{Jenis-jenis Multimedia}

Multimedia memiliki beberapa jenis atau kategori berdasarkan pengertiannya. Jenis atau kategori multimedia antara lain:

\section{a. Multimedia linier}

Multimedia linier adalah multimedia yang tidak dilengkapi dengan alat pengontrol yang dapat dioperasikan oleh pengguna. Multimedia linier berjalan sekuensial (berurutan).

b. Multimedia interaktif

Multimedia interaktif adalah multimedia yang dilengkapi dengan alat pengontrol yang dapat dioperasikan oleh pengguna sehingga pengguna dapat memilih apa yang dikehendaki untuk proses selanjutnya.

\section{METODE}

Penelitian ini dilakukan dilakukan di SD Negeri 050748 yang beralamat di P. Berandan Kec. Babalan dengan jumlah siswa sebanyak 36 orang. Waktu penelitian ini dilakukan pada bulan Agustus dan berakhir pada bulan September Tahun Pelajaran 20162017. Metode penelitian yang digunakan adalah Penelitan Tindakan Kelas (PTK) yang terdiri dari 2 siklus.

Siklus I terdiri dari perencanaan, pelaksanaan, observasi dan refleksi. Pada siklus I peneliti membuat perencanaan untuk membantu meningkatkan hasil belajar PKn siswa.Kemudian, pada tahap 
pelaksaaan, peneliti menerapkan model Numbered Head Together (NHT) berbantu multimedia. Pelaksanaanya dilakukan selama satu pertemuan dengan materi pengertian keputusan bersama dan cara-cara pengambilan keputusan bersama. Tahap refleksi dilakukan pada akhir pembelajaran yang dilakukan oleh mengenai kegiatan pembelajaran PKn menggunakan model Numbered Head Together (NHT) berbantu multimedia. Dengan melaksanakan refleksi, peneliti dapat membuat rencana kegiatan untuk siklus berikutnya.

Siklus II terdiri dari perencanaan, pelaksanaan, observasi dan refleksi. Tahap perencanaan yang dilakukan pada siklus kedua adalah memperbaiki dan menyempurnakan pembelajaran yang telah dilakukan pada siklus pertama. Pada siklus kedua ini peneliti menerapkan model Numbered Head Together (NHT) berbantu multimedia. Pelaksanaannya dilakukan selama satu pertemuan. Kemudian, repfleksi dilakukan berdasarkan hasil pengamatan yang terjadi pada siklus kedua, peneliti menemukan peningkatan yang maksimal dalam kualitas belajar Pendidikan Kewarganegaraan pada siswa kelas V SD Negeri 050748 Pangkalan Berandan Tahun Pelajaran 2016-2017.

Teknik pengumpulan data yang digunakan yaitu teknik tes dan non tes. Teknik tes digunakan untuk mengukur hasil belajar siswa yaitu dari hasil tes formatif siswa pada siklus I dan siklus II. Tes formatif dilaksanakan pada setiap akhir siklus. Hasil tes formatif siswa juga digunakan untuk menghitung nilai rata - rata kelas dan menghitung tuntas belajar klasikal. Sedangkan teknik non tes digunakan guru dalam kegiatan pengamatan dan dokumentasi. Guru melakukan pengamatan terhadap aktivitas belajar siswa dalam proses pembelajaran. Analisis data dengan menentukan nilai rata-rata kelas dan persentase ketuntasan belajar siswa. Pelajaran PKn dikatakan berhasil apabila indikator keberhasilan yang ditentukan dapat tercapai yaitu $80 \%$ siswa.

\section{HASIL DAN PEMBAHASAN}

1. Hasil

Penelitian dilakukan melalui siklus 1 dan siklus 2. Pada siklus awal, hasil belajar siswa masih sangat rendah. Terlihat dari nilai ratarata yang berhasil dicapai hanya 64,44 dengan persentase ketuntasan mencapai $44,44 \%$ dan hasil presentasi ini masuk dalam kategori 
kurang. Hal ini disebabkan karena metode yang digunakan kurang menarik minat siswa mengikuti pembelajaran PKn. Sedangkan hasil penelitian siklus I, hasil belajar siswa mengalami peningkatan setelah diberikannya tindakan. Hal itu dapat dillihat dari nilai rata-rata yang diperoleh mencapai 71,11 dengan persentase ketuntasan mencapai $66,66 \%$. Hasil ini masuk dalam kategori Baik. Siklus terakhir yaitu siklus II, hasil belajar siswa semakin meningkat. Hal itu bisa dilihat dari jumlah nilai rata-rata yang berhasil diperoleh yaitu 80 dengan persentase mencapai $83,33 \%$. Melihat hasil yang semakin baik, maka nilai hasil belajar pada siklus II masuk dalam kategori "baik sekali".

\section{Pembahasan}

Berdasarkan penelitian dapat diketahui bahwa hasil belajar siswa SD Negeri 050748 Pangkalan Berandan Tahun Pelajaran 20162017 dalam pembelajaran PKn masih sangat rendah. Hal itu dikarenakan kurangnya keterampilan guru mengolah kelas dan penggunaan metode pembelajaran yang belum optimal sehingga berdampak pada hasil belajar siswa. Siswa jadi malas belajar, cepat bosan, mudah mengantuk dan lebih banyak menghabiska waktu belajar dengan bermain atau mengganggu teman lainnya. Untuk itu peneliti menggunakan metode Numbered Heads Together berbantuan multimedia yang diyakini bisa meningkatkan hasil belajar. Setelah diterapkannya metode Numbered Heads Together dalam pembalajaran PKn hasil belajar siswa mengalami peningkatan.

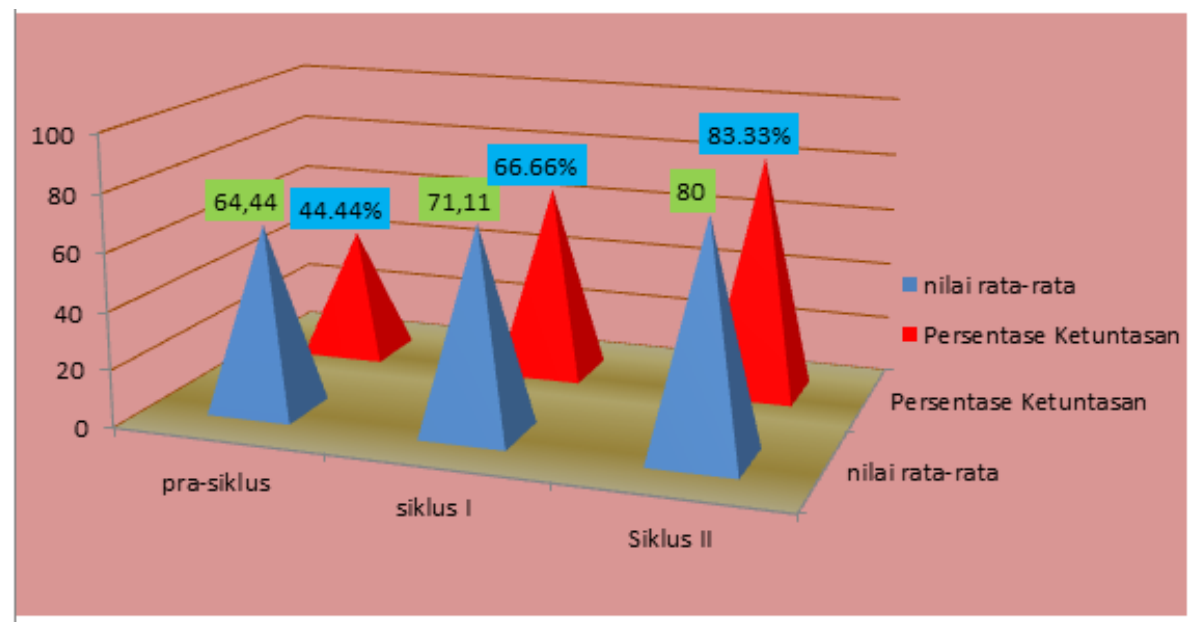


Gambar 1. Diagram Rekapitulasi Nilai Hasil Belajar

Berdasarkan diagaram diatas dapat dilihat bahwa hasil belajar siswa pada pra-siklus hanya mencapai nilai rata-rata 64,44 dengan persentase ketuntasan mencapai $44,44 \%$. Hal ini dikarenakan pada pra-siklus belum diberikan tindakan pembelajaran. Namun setelah diberikannya tindakan, hasil belajar siswa mengalami peningkatan. Hal itu dapat dilihat dari hasil belajar yang diperoleh pada siklus I mencapai nilai rata-rata 71,11 dengan persentase ketuntasan $66.66 \%$. Dan semakin meningkat lagi pada siklus II dengan perolehan nilai rata-rata mencapai 80 dan pesentase ketuntasannya mencapai $83,33 \%$. Selain peningkatan hasil belajar, aktivitas siswa selama mengikuti pembelajaran PKn juga meningkat. Hal itu dikarenakan siswa sudah tertarik untuk mengikuti pembelajaran PKn dan sudah paham mengenai metode pembelajaran yang diterapkan. Melihat peningkatan yang terjadi dapat disimpulkan bahwa dengan metode Numbered Heads Together berbantuan multimedia dapat meningkatkan hasil belajar khususnya pada pembelajaran PKn pada siswa kelas V SD Negeri 050748 Pangkalan Berandan Tahun Pelajaran 2016-2017.

\section{E. SIMPULAN}

\section{Kesimpulan}

Berdasarkan hasil penelitian terhadap hasil belajar PKn melalui Numbered Head Together (NHT) metode berbantuan multimedia pada siswa di SD Negeri 050748 Pangkalan Berandan Tahun ajaran 20162017 diperoleh hasil bahwa Model Numbered Head Together (NHT) berbantu multimedia meningkatkan hasil belajar siswa. Hal ini dapat dilihat dari data prasiklus dengan nilai rata-rata 64,44 dan perentase ketuntasan 44,44\% meningkat pada siklus I menjadi rata-rata kelas 71,11 dengan persentase ketuntasan $66,66 \%$. Pada siklus II rata-rata kelas meningkat menjadi 80 dengan persentase ketuntasan 83,33\%. Dengan demikian hasil belajar siswa telah mencapai KKM yang telah ditentukan oleh pihak sekolah.

\section{Saran}

Hasil penelitian ini dapat memberikan konstribusi dalam meningkatkan kualitas pembelajaran PKn di SD. Dan saran yang dapat disampaikan yaitu: 
1. Sebagai bahan masukan bagi guru dalam melaksanakan pembelajaran khususnya pembelajaran Pendidikan Kewarganegaraan untuk menggunakan metode numbered heads together berbantuan multimedia sehingga pembelajaran menjadi lebih optimal dan menyenangkan.

2. Sebelum melaksanakan pembelajaran, sebaiknya guru menyiapkan segala kebutuhan yang diperlukan baik itu metode ataupun media dengan sebaik-baiknya.

3. Kepada guru sebaiknya lebih kreatif dan variatif dalam menggunakan metode pembelajaran. Hal ini akan menghilangkan kejenuhan kepada siswa selama mengikuti proses pembelajaran.

4. Guru dalam mengajar hendaknya melibatkan siswa secara aktif agar siswa merasa lebih dihargai dan diperhatikan sehingga akan meningkatkan perilaku belajar yang baik.

\section{F. DAFTAR PUSTAKA}

Depdiknas. 2007. Naskah Akademik Kajian Kebijakan Kurikulum Mata Pelajaran Pendidikan Kewarganegaraan. Jakarta: Pusat Kurikulum Badan Penelitian dan Pengembangan Departemen Pendidikan Nasional.

Shoimin, A. 2014. 68 Model Pembelajaran Inovatif dalam Kurikulum 2013. Yogyakarta: Ar-Ruzz Media.

Sisdiknas. 2005. UU No 20 Tahun 2003. Jakarta: Redaksi Sinar Grafika.

Trianto. 2011. Model Pembelajaran Terpadu Konsep, Strategi dan Implementasinya Dalam KTSP. Jakarta: Bumi Aksara. 